Postprint: MOON, K. , ADAMS, V. M., JANUCHOWSKI-HARTLEY, S. R., POLYAKOV, M. , MILLS, M. , BIGGS, D. , KNIGHT, A. T., GAME, E. T. and RAYMOND, C. M. (2014), A Multidisciplinary Conceptualization of Conservation Opportunity. Conservation Biology, 28: 1484-1496. doi:10.1111/cobi.12408

\title{
A MULTIDISCIPLINARY CONCEPTUALIZATION OF CONSERVATION OPPORTUNITY
}

Katie Moon ${ }^{1}$, Vanessa M. Adams ${ }^{2}$, Stephanie R. Januchowski-Hartley ${ }^{3}$, Maksym Polyakov ${ }^{4}$, Morena Mills $^{5}$, Duan Biggs ${ }^{6}$, Andrew Knight ${ }^{7,8}$, Edward T Game ${ }^{9}$, Christopher M

Raymond $^{10,11}$

\footnotetext{
${ }^{1}$ Institute for Applied Ecology/ANZSOG Institute for Governance, University of Canberra, Bruce, ACT 2601 Australia, katieamoon@gmail.com Ph: +61 26206 3812, Fax: +61 262015608

${ }^{2}$ Research Institute for the Environment and Livelihoods, Charles Darwin University, Darwin NT 0909, Australia

${ }^{3}$ Center for Limnology, University of Wisconsin-Madison, Madison, WI 53706 USA.

${ }^{4}$ Centre for Environmental Economics and Policy, School of Agricultural and Resource Economics, University of Western Australia, University of Western Australia, Crawley, WA, 6009, Australia

${ }^{5}$ Global Change Institute, The University of Queensland, Brisbane, QLD 4072, Australia

${ }^{6}$ Australian Research Council Centre of Excellence for Environmental Decisions, Centre for Biodiversity and Conservation Science, University of Queensland, Brisbane, QLD 4072, Australia

${ }^{7}$ Department of Life Sciences, Imperial College London, Silwood Park Campus, Buckhurst Road, Ascot, BRK, SL5 7PY, United Kingdom

${ }^{8}$ Department of Botany, Nelson Mandela Metropolitan University, P.O. Box 77000, Port Elizabeth 6031, South Africa

${ }^{9}$ The Nature Conservancy, 245 Riverside Drive, West End, QLD 4101, Australia

${ }^{10}$ School of Commerce and Barbara Hardy Institute, University of South Australia

${ }^{11}$ Enviroconnect, PO Box 190, Stirling SA 5152
} 


\begin{abstract}
An opportunity represents an advantageous combination of circumstances that allows goals to be achieved. We reviewed the nature of opportunity and how it manifests in different subsystems (e.g., biophysical, social, political, economic) as conceptualized in other bodies of literature, including behavior, adoption, entrepreneur, public policy, and resilience literature. We then developed a multidisciplinary conceptualization of conservation opportunity. We identified 3 types of conservation opportunity: potential, actors remove barriers to problem solving by identifying the capabilities within the system that can be manipulated to create support for conservation action; traction, actors identify windows of opportunity that arise from exogenous shocks, events, or changes that remove barriers to solving problems; and existing, everything is in place for conservation action (i.e., no barriers exist) and an actor takes advantage of the existing circumstances to solve problems. Different leverage points characterize each type of opportunity. Thus, unique stages of opportunity identification or creation and exploitation exist: characterizing the system and defining problems; identifying potential solutions; assessing the feasibility of solutions; identifying or creating opportunities; and taking advantage of opportunities. These stages can be undertaken independently or as part of a situational analysis and typically comprise the first stage, but they can also be conducted iteratively throughout a conservation planning process. Four types of entrepreneur can be identified (business, policy, social, and conservation), each possessing attributes that enable them to identify or create opportunities and take advantage of them. We examined how different types of conservation opportunity manifest in a social-ecological system (the Great Barrier Reef) and how they can be taken advantage of. Our multidisciplinary conceptualization of conservation opportunity strengthens and legitimizes the concept.
\end{abstract}

Keywords: case studies, conservation actions, entrepreneur, opportunity exploitation, socioecological system, window of opportunity 


\section{Introduction}

The ongoing global loss of biodiversity and degradation of ecosystems has resulted in understanding that conservation research needs to refocus on developing effective conservation solutions (Balmford \& Cowling 2006; Ehrlich \& Pringle 2008). The effectiveness of conservation solutions depends upon social, political and economic constraints and opportunities, across institutions, individuals and spatial and temporal scales (Chan et al. 2007; Cowling \& Wilhelm-Rechmann 2007; Ekoko 2000; Payne 2000). The concept of conservation opportunity emerged to ensure that social factors necessary to implement conservation actions were included in conservation planning spatial prioritizations (Knight et al. 2010). Increasingly, conservation scientists recognize that an assessment of conservation opportunity can help bridge the knowledge-implementation gap in conservation planning (e.g., Game et al. 2011; Pressey \& Bottrill 2009).

The development of an operationally useful conceptualization of conservation opportunity, however, is still in its infancy. In attempting to understand and define conservation opportunity, researchers have identified or assessed a multitude of factors, which can be broadly themed into ecological dimensions of conservation priority, including conservation value and vulnerability (see Pressey 1997) and economic and social dimensions of the feasibility of action (e.g., Mills et al. 2013; Naidoo et al. 2006; Rollings \& Brunckhorst 1999). The social characteristics that can enable the implementation of actions within a social-ecological system can vary widely, from the characteristics of the users of the resource (e.g. knowledge, goals) to those of the governance system in place (rules, how these rules were established) (Ostrom 2009). Consequently, these characteristics are increasingly being considered in conservation initiatives and integrated into existing frameworks. For example, Ban et al. (2013) highlight the need to link existing understandings of social-ecological systems to the systematic conservation planning process. In monitoring and evaluation, Fox et al. (2014) used the social-ecological systems framework (Ostrom 2009) to understand the social and ecological effects of marine protected areas. Linking conservation initiatives to diagnostic tools, such as the social-ecological systems framework, increases conservation scientists' capacity to understand which characteristics of the system allow for conservation actions to be implemented, leading to a more effective integration of social considerations in conservation initiatives. 
Looking outside of conservation literature, different theories and models of opportunity have been developed and used within other disciplines, and applied to different subsystems of the social-ecological system. These varied theories and models provide different perspectives about how opportunity could be created, discovered or accessed across and within different biophysical, social, political and economic sub-systems (of the social-ecological system) to achieve conservation outcomes. Explorations of the concept of opportunity are prevalent in the behavior, adoption, business, entrepreneur, institutional, public policy, resilience and uncertainty and mainstreaming literatures. Within these disciplines, the concept of opportunity is explored because it has been identified as crucial for achieving desirable outcomes or futures of a system. Each of these bodies of literature define, conceptualize and operationalize opportunity in different ways, complementing the broader social-ecological systems theory, ranging from opportunities that can be exploited for commercial gains in economic sub-systems (Holcombe 2003), through to opportunities to support individual actors to adopt innovations (Rogers 2003). To advance the concept of conservation opportunity, we encourage conservation scientists and practitioners to understand and apply these different interpretations of opportunity.

In this paper, we provide a multidisciplinary conceptualization of opportunity to identify and harness conservation opportunity within complex social-ecological systems. Specifically, we: 1) identify how opportunities have been defined, conceptualized and operationalized in nine different bodies of literature; define three types of conservation opportunity; 2) define the skills and attributes of four types of entrepreneur who can create and harness opportunities; and, 3) present a summarized, five-step process to operationalize conservation opportunity. We conclude with a discussion of future areas of research that could strengthen the field of conservation opportunity to improve conservation outcomes.

\section{Reviewing the concept of opportunity}

\section{Behavior and adoption}

In behavioral theory, behavior is considered a product of an opportunity and intent, which is a function of relationships, processes and drivers of behavior, including values, attitudes, worldviews, responsibility, moral commitment, place attachment, norms, habits, goals, affect and demographic factors (Fishbein 1967; Gifford 2014). For example, the theory of planned behavior (TPB) aims to understand the relationships between attitudes and behaviors (Ajzen 
1985; Fishbein \& Ajzen 2005), where the strongest predictor of an individual's behavior is his/her intention to act, which is caused by attitudes, subjective norms and perceived behavioral control (Schultz \& Estrada-Hollenbeck 2008). This literature indicates that opportunities for conservation are more likely when the action is associated with a favorable cost-benefit analysis of adopting the innovation, greater perceived normative support for the practice and lower perceptions of the extent to which barriers would impede the management of natural resources (Beedell \& Rehman 1999; Fielding et al. 2005; Kaiser 1998).

Opportunities for conservation can also be influenced by the way in which conservation practices appeal to a person's moral obligations, as explained by the norm activation model (Schwartz 1977) and value-belief-norm theory of environmental action (Stern et al. 1999). Recognizing opportunities relies on identifying these patterns of human behavior (Ray \& Cardozo 1996).

In adoption theory (Rogers 2003), opportunities are sought for individual or institutional adoption of innovations such as products, technologies, or practices. Adoption has elements in common with the entrepreneur and business theory but specifically focuses on three aspects of adoption. The first aspect relates to the characteristics of the innovation: profitability, riskiness and complexity. Of particular importance is the relative advantage of the innovation: the degree to which the innovation is perceived to be better than the product, technology or practice that it replaces (Rogers 2003). The second aspect explores the characteristics of the potential adopter, including a person's emphasis on profit, attitude to risk and time commitments. Adoption theory is commonly used to understand individuals' willingness to adopt conservation or agricultural practices (Kabii \& Horwitz 2006; Sattler \& Nagel 2010; Traoré et al. 1998), including the behavioral models mentioned above. The third aspect explores how the social, political and economic sub-systems (e.g., laws, culture social norms and ideologies) shape the environment where adoption takes place (Rogers 2003; Wejnert 2010). All of these aspects of adoption can contribute to time lags before full adoption, and in many cases lags can be long (decades).

\section{Business, entrepreneurs and institutions}

In business, opportunities are sought for business development and economic change. Within the business literature, the concept of opportunity is pervasive, i.e. the belief that there is always an opportunity to do something better or different, irrespective of whether or not that opportunity is being exploited. We begin our review with entrepreneurship because it 
explores the operational aspects of opportunity (Shane \& Venkataraman 2000).

Entrepreneurship involves the discovery, evaluation and exploitation of opportunities to introduce new markets, processes, raw materials and goods and services that previously had not existed (Shane 2003). Opportunities are typically discovered and exploited with the purpose of increasing profit, but may also relate to other measures such as increased market share. Entrepreneurial opportunity can be broadly grouped into opportunities that pre-exist outside of the entrepreneur (perceived or recognized), and opportunities that are created and exploited by the entrepreneur (Short et al. 2010). Important aspects of entrepreneurial opportunity include the characteristics of individual entrepreneurs (e.g., Begley \& Boyd 1987; Brockhaus \& Horwitz 1986) that enable them to recognise and act upon opportunities succesfully (Holcombe 2003; Shane 2003), and the characteristics of the sub-system within which opportunities manifest (e.g., market processes and exogenous shocks). The Individual - Opportunity Nexus (ION) theory is particularly relevant to the conservation domain because it brings together the study of the individual characteristics of entrepreneurs, the sources of opportunity and the processes of discovering opportunities (Shane 2003).

Following the ION framework, opportunity existence, discovery, evaluation and exploitation happens in a sequential fashion (potentially with feedbacks). Commonly, opportunities exist relative to specific and well-defined problem and solution pairs (Hsieh et al. 2007; Plummer et al. 2007). Understanding the system in which the problem-solution pair exists is critical (Shane 2003), and usually exists as a function of the economic (e.g., does demand exist and can it be met at reasonable cost?) and social (e.g., who does the entrepreneur know/work with?) sub-systems. Opportunity discovery relates to both the individual characteristics of entrepreneurs (e.g., prior knowledge, awareness, motivation) and the processes they undertake to discover opportunities (e.g., networking with entrepreneurs and scanning for new technological advances). The entrepreneur must then evaluate any discovered opportunity (i.e., assess the feasibility of exploiting the opportunity) and if feasible, exploit it.

Institutional change, whereby a change agent (trustworthy, credible, sincere, expert) acts to influence beliefs, attitudes and ultimately behavior, contributes to the creation of opportunities for entrepreneurial activity (Sine \& David 2003). Much of the institutional change literature links back to human relationships, processes and drivers of behavior. For example, sets of socially-constructed logics (i.e. values, beliefs, assumptions) can define appropriate behaviors, structures and practices within an organization, changes in which can 
create entrepreneurial opportunities (Sine \& David 2003). Similarly, an 'opportunity set' includes the formal rules (e.g. laws, regulations), informal constraints (e.g. norms, conventions) and enforcement characteristics in the economy that entrepreneurs can modify to support the existence of an organization or group (North 1995). The concept of 'readiness for change', suggests that readiness relies on: 1) a need for change: a discrepancy between the existing state and a desired state; and, 2) the perceived ability of (collections of) individuals to change: efficacy (Armenakis et al. 1993) (see also Morris \& Potter 1995). Importantly, individuals must agree that the end state is desirable and that change is necessary. To influence people, change agents adopt a number of strategies: persuasive communication, active participation, and/or management of external sources of information. Different programs can be designed according to the readiness of the people needing to change, and the urgency of change (e.g., aggressive, crisis, maintenance or rapid response).

\section{Public policy}

In public policy, opportunities are sought for agenda change and can be explained by three dominant theories of policy development and evolution. Each of these theories considers the processes and drivers of the system in which policies are developed and which are amenable to change, and the characteristics of individuals and groups that seek to modify logics and opportunity sets. The theory of policy streams explains that infrequent and short-lived "windows of opportunity" open when the problem, policy and politics streams of policy subsystems align. During this time, new subjects of political attention can be placed on the agendas of governments and subsequently the agendas for decision-making and action (e.g., proposals for legislative enactment) (Kingdon 1984). The theory of punctuated equilibrium explains that opportunities exist to interrupt the policy sub-system, which is comprised of policies that are not gradual and incremental but respond to external perturbations in disjointed and episodic ways (Baumgartner \& Jones 1993). Advocacy coalition framework theory describes how coordinated groups with a shared belief (i.e., advocacy coalitions) can create significant policy changes by translating their beliefs into governmental programs, or driving external changes (e.g., socio-cultural values) that will influence the policy sub-system (Sabatier 1988).

Opportunity relates to the policy sub-system, which is comprised of the problem, policy and political streams (Kingdon 1984) and tends to be dominated by 'policy monopolies' that favor privileged interest groups (e.g., advocacy coalitions) and ignore others (Baumgartner \& 
Jones 1993). Like entrepreneurialism, opportunities to influence policy development rely on connecting clearly-defined problems with feasible solutions (Baumgartner \& Jones 1993; Kingdon 1984). 'Policy entrepreneurs' seek to define problems in ways that ensure they receive political attention and promote particular solutions to increase their likelihood of adoption. Similarly, advocacy coalitions use peoples' deep core (e.g., basic philosophy, religion); 2) and policy core (e.g., environmental protection versus economic development) belief systems to change political agendas (Sabatier 1988).

\section{Resilience and uncertainty}

The purpose of behavior is to change the future on the basis of an inference of the present, which requires perception and twofold inference: people infer a future without interference, and a future with change induced by human action (Knight 2012). Scenarios of the future are made uncertain because of unknown behaviors of actors in the system, and unknown system dynamics and drivers (Peterson et al. 2003). Some uncertainties can be objectively measured to generate probabilities of particular outcomes (termed risks), while other uncertainties are immeasurable, whereby only subjective predictions can be made (Knight 2012). Cultural theory is often used to explain patterns in how people approach and interpret uncertain futures. With respect to the natural environment, for example, people can see nature as resilient, responsive and opportunistic (individualists); as fragile and vulnerable (egalitarians); as tolerant within limits (hierarchists); or as unpredictable (fatalists) (O'Riordan \& Jordan 1999). These groups somewhat reflect the different bodies of literature that examine uncertainty of future scenarios, three of which we have chosen to review here on the basis of their relevance to conservation and opportunity.

Resilience thinking is used to scope problems from broad perspectives and multiple viewpoints to provide opportunities for actors to structure systems towards a desired trajectory (Fischer et al. 2009; Polasky et al. 2011). Resilience thinking, coupled with scenario planning examines the probabilities of different system states resulting from interventions and interactions, including states not currently identifiable or considered probable (Polasky et al. 2011). It also explores drivers of system change, system thresholds and alternative system states (Cumming et al. 2005; Walker et al. 2002), seeking to reduce the risks of unforeseen events or unintended consequences, such as attempting to control systems or reduce perceived risks that could lead to phase shifts (Fischer et al. 2009; Polasky et al. 2011). The aim of applying resilience thinking is to strengthen the capacity of a system 
to remain in, or be managed towards, a desired state along a desired trajectory (Walker et al. 2002). The resilience literature discusses 'windows of opportunity' as those that can result in transformations in a system, which can be triggered by a resource crisis or a shift in social values (Walker et al. 2006), and that can enable novel policy solutions that were not previously possible to develop and implement (Folke et al. 2005).

In the field of risk assessment, opportunities are sought for positive outcomes from uncertain situations, typically by hierarchists (O’Riordan \& Jordan, 1999). Traditionally, the field has focused on evaluating and managing uncertainties with potentially negative effects on project objectives (Lewin 2002). Uncertainty, however, can also result in positive outcomes (Ney \& Thompson 2000). The rationale for considering both positive and negative effects on a project, down-side (threats) and up-side (opportunities) risk respectively, in a risk assessment is that both can influence the success of a project (Ward \& Chapman 2003). Considering down-side and up-side risks as part of the same process ensures that opportunities for positive outcomes are identified and acted on at the outset of any given process (Hillson 2002).

Information-gap decision theory (IGDT) (Ben-Haim 2006) is used to seek opportunities that exceed expected outcomes under severe uncertainty. IGDT is a technique that offers a nonprobabilistic approach to decision-making when facing uncertainty, ignorance, or potential surprise about the values of parameters or shapes of functional relationships between variables (Hayes et al. 2013). The theory consists of a model of the system, a model of uncertainty, and a set of performance requirements for the potential solution to the problem, specified by the decision-maker. Possible solutions to the problem, operationalized within biophysical, social, political and/or economic sub-systems, are identified based on their "robustness" and "opportuneness". Robustness measures how wrong estimates of uncertain parameters of the model can be before the outcome of the solution to the problem falls below an acceptable level (Burgman et al. 2005). Opportuneness assesses the lowest amount of uncertainty at which better than anticipated outcomes (known as windfalls) can occur. In this context, opportunity is thought of as the likelihood that an outcome of a solution exceeds expectations (Regan et al. 2005).

\section{Mainstreaming}

The process of mainstreaming seeks opportunities to internalize biodiversity conservation goals and sustainable biological resource use into systems, policies and programs, and ultimately, all human behavior (Huntley \& Petersen 2005). Mainstreaming attempts to 
understand and engage with the complex and interacting dimensions of systems, as well as individuals' psychology, bringing together many of the underlying elements of the literature that explain patterns of opportunity identification and creation. Mainstreaming is depicted through a conceptual framework that details prerequisite conditions, stimuli and mechanisms that define a system state in which conservation opportunity can be identified and/or created. Opportunity is acknowledged to be of fundamental importance in achieving conservation goals through mainstreaming by, for example, responding to unexpected favorable conditions that emerge (e.g., a change in government policy), responding to a crisis that demands action (e.g., catastrophic decline of biodiversity) or attempting unsolicited intervention (e.g., assisting business to change their policies). Pre-empting the challenges of mainstreaming for manifesting conservation opportunity begins by identifying the elements of the system through which conservation opportunity can manifest (Clark 2002; Cowling \& WilhelmRechmann 2007; Knight et al. 2006).

\section{Summary}

Several themes are common across the disciplines in terms of how opportunity is conceptualized. Opportunities are predominantly sought to create change of some kind, which relies on understanding the structure of institutions and human behavior, including skills, attributes and decision-making processes of individuals. The dynamics of the (sub) system and characteristics of individuals determines the nature of opportunities and the likelihood that they can and will be taken advantage of. While some processes and system changes can be unpredictable, identifying predictable or fundamental drivers of individuals' decision-making could assist in explaining many of the underlying patterns and processes of opportunity creation and exploitation as identified in the different bodies of literature. To illustrate, opportunities must exist for conservation priorities to be translated into action, and must be followed by an intent to pursue the action. Intent to pursue an action is driven by underlying motivations of the individual (values, attitudes, and beliefs), the socio-ecological context in which the opportunity manifests, and the characteristics of both the opportunity and the action. Below we define different types of opportunities and entrepreneurs relevant to conservation planning on the basis of these patterns and processes.

\section{Defining types of conservation opportunity and entrepreneurs}

Three types of opportunity were consistently identified in the bodies of literature we reviewed (Table 1), which we define as potential, traction and existing opportunities. 
Different leverage points characterize each of these opportunity types. For example, potential opportunities can be leveraged from education, while traction opportunities can be leveraged from disease outbreaks (Table 2).

In addition to defining three types of opportunity, our literature review identified four different types of entrepreneurs who can identify or create conservation opportunities: business, policy, social and conservation entrepreneurs (Table 3). The literature describes entrepreneurs as having strong leadership skills, a tolerance for ambiguity and high selfefficacy, and a tendency to be efficient and effective at identifying opportunities (Gaglio \& Katz 2001). Typically, entrepreneurs discover opportunities, bear the risk involved in exploiting an opportunity, and have skills to assemble or coordinate a team to take advantage of an opportunity (Acs \& Audretsch 2010). The four types of entrepreneur we identify, however, have unique skills and attributes that enable them to influence different elements of the (sub) system in different ways to achieve conservation outcomes.

Potential opportunities are available in (sub) systems that are not yet 'primed' to support conservation actions. In other words conservation action might not yet be feasible, and entrepreneurs must remove barriers to problem-solving by identifying the capabilities within the system that can be manipulated to create support for conservation action (Armenakis et al. 1993). Potential opportunities, identified in several bodies of literature (Table 1), can pave the way for traction and existing opportunities. Potential opportunities occur in social, political and economic sub-systems, within which barriers to solving problems typically reside (e.g., lack of political support or funding, low stakeholder willingness to participate in a conservation program).

Traction opportunities represent 'windows of opportunity' that arise from exogenous shocks, events or changes that can be used to draw the system towards a desired state (e.g., Kingdon 1984). Traction opportunities, identified by all literatures we reviewed (Table 1), change across time and space. Large-scale perturbations or crises are usually visible (e.g., disease outbreaks, social revolutions, natural disasters), particularly to policy and conservation entrepreneurs who position themselves to capitalize on traction opportunities (Table 3), yet they are often unpredictable. Small-scale perturbations can be more predictable, such as in relation to supply-and-demand (e.g., oil and gas shortages) or changing conditions (e.g., a shift in a local community's perceptions of a conservation problem). 
Existing opportunities occur when everything is in place for conservation action and an entrepreneur only needs to take advantage of the existing circumstances (e.g., Chandra et al. 2009). Existing opportunities relate to opportunity discovery as discussed in the entrepreneurial and adoption literature (Table 1). They also relate to upside risk, defined in the risk literature, because in situations of high uncertainty, they can be perceived as 'threats', reducing the likelihood that the opportunity will be exploited (Ward \& Chapman 2003). Other times, no one has attempted to identify them or they are not readily identifiable (e.g., an opportunity may differ subtly to existing properties of the system and so only the most alert entrepreneur(s) can identify it, Holcombe 2003).

\section{Operationalizing conservation opportunity}

Opportunities for conservation can materialize and vaporize very quickly, sometimes in a matter of hours, days or weeks. Synthesizing the literature, we identified five stages of successful opportunity identification/creation and exploitation, a priori knowledge of which will enable actors, including entrepreneurs, to generate the most effective conservation outcomes (Figure 1). Several of these stages have been identified by other authors with regards to formulating and managing conservation projects (CMP 2013; Salafsky et al. 2002). In this paper, however, we isolate and offer these stages as critical precursors to the clear identification of conservation opportunities. Due to the ephemeral nature of some opportunities, it might not always be possible for an actor to give consideration to all stages.

\section{Characterize the system and define any problems}

The opportunity to conserve will be determined by the unique characteristics of the spatially and temporally bound system from which it emerges. A variety of tools, including the policy sciences framework (e.g., Clark 2002), resilience assessment (Resilience-Alliance 2010) and logic and conceptual models (e.g., applying a theory of change, Bradach et al. 2008) can assist in characterizing the system, including identifying underlying processes (e.g., attitudes, bounded rationality) (Simon 1991) that contribute to conservation problems. Only once the system is characterized can problems be accurately defined, because problems in themselves can involve complex systems and processes that relate to an extensive number of decisions that interact in complicated ways; a problem is the 'entrepreneurial unit of analysis' (Hsieh et al. 2007). Defining a problem is an important part of identifying possible solutions, and involves defining the scope and nature of the problem, clarifying the goals and expectations 
of affected people or groups, and understanding individuals' standpoints and biases (Clark 2002; Cundill et al. 2012).

\section{Identify the solutions}

Once problems are well-defined, solutions can be developed. Actors can search the solution landscape for viable, cost-effective solutions in several ways. They can engage, for example, in 'directional' searching through a process of experimental trial-and-error between choices, or through developing mental models (i.e., cognitive maps) that use heuristics or theories about the unseen solution landscape to discover opportunities (Hsieh et al. 2007). Agreement on a solution and desired future state can be achieved through participatory objective setting, sharing mental models and visioning processes (e.g., Biggs et al. 2011; Walker et al. 2002). For example, visioning processes could involve setting qualitative goals, which reveal biophysical, social and economic data sets that need to be collected, leading to defined quantitative conservation objectives (i.e., solutions) (Pressey \& Bottrill 2009). In some instances, a set of solutions could be necessary to solve one problem or one solution could be necessary to solve a set of problems (Hsieh et al. 2007).

\section{Assess the feasibility}

Typically, a range of alternative solutions are proposed and explored before one or more are implemented; implemented solutions are those that are deemed most feasible and likely to succeed (Kingdon 1984). Several bodies of literature we reviewed included feasibility as an important characteristic of opportunity that would indicate whether or not it would be worthwhile to invest resources to exploit the opportunity. Feasibility can be defined as the ability of a proposed combination of resources to deliver a specified value/success (Ardichvili et al. 2003). In selecting the most feasible solution, a range of factors can and have be considered, including: 1) economic costs and relative advantage (e.g., Pannell et al. 2006); 2) individual and collective factors that influence decision-making (e.g., Armenakis et al. 1993); 3) governance arrangements, policies and political sub-systems that regulate resource use (e.g., Mills et al. 2013); and 4) up-side and down-side risks, including uncertainty in decision-making and action (e.g., Ward \& Chapman 2003). Spatial assessments can be used to map some of these factors to identify areas in which opportunities for conservation are most likely (Knight et al. 2010). 
The feasibility of actions will often depend on the extent to which individuals or groups are willing to collaborate or change, reflecting the importance of understanding influences on human behavior in achieving conservation outcomes. Armenakis et al. (1993) explain that change requires convincing a collection of socially-interacting individuals to change their beliefs, attitudes and behavioral intentions. When the feasibility of conservation actions relies on involving individuals and communities to collaborate or change, assessments of individual and collective readiness to engage in a conservation action can be conducted to assess people's interpretation of the need for the solution/s and their willingness to engage with them. Assessments of readiness and urgency can help define the type of approach that is necessary. Not all conservation actions, however, will require collaboration. Feasibility is also influenced by a variety of technical and administrative factors, including the level of uncertainty associated with the assessment (Lechner et al., this issue), the spatial grain size at which biological and social data are integrated (Sutton and Armsworth, this issue) and the cost of social data collection (Tulloch et al, this issue).

\section{Identify the type of opportunity}

Once feasibility has been assessed, one of the three types of opportunities to implement the solution can be sought, including screening to isolate inappropriate opportunities (Ehrlich \& Pringle 2008). An important initial question to ask in this step is: for what is an opportunity being sought? (Walker et al. 2002). Recognizing and exploiting opportunities effectively and efficiently will depend to a large extent on the answer to this question, primarily because it keeps the focus on the problems and solutions of the system (Walker et al. 2002). Tools such as scenario planning, horizon scanning and fore sighting exercises (e.g., Bradach et al. 2008; Polasky et al. 2011; Walker et al. 2002) can be used to identify possible opportunities (and threats). Cook et al. (this issue) provide a comprehensive review of foresight tools for recognizing and realizing conservation opportunities. Risk assessments and IGDT can be used determine the probability of an opportunity occurring and the certainty of that probability. Strategic structuring of teams to improve their entrepreneurial capacity will also contribute to successful opportunity identification and exploitation.

\section{Take advantage of the opportunity}

Once an opportunity is identified, it must be successfully taken advantage of. Entrepreneurs realize opportunities through a process of recognition, evaluation and development. This process can often be cyclical and iterative, requiring multiple evaluations at different stages 
of development and resulting in changes to solutions and/or development of additional opportunities (Ardichvili et al. 2003). Several factors increase the likelihood of an entrepreneur's 'alertness': prior knowledge, experience, personality traits and social networks (Ehrlich \& Pringle 2008). Often, individuals and collectives (e.g., organizations), either with a common goal or complementary skill sets, will need to partner with one another to develop and take advantage of the opportunity (Table 3). For example, policy entrepreneurs seek ongoing funding and political support for a scheme, economists develop incentive schemes and conservation practitioners engage landholders.

\section{A case of the Great Barrier Reef Marine Park}

We draw on the case of the Great Barrier Reef (GBR), a well-known conservation example that spans five decades, to illustrate how different types of opportunities for conservation can be operationalized over time (see Figure 2 for timeline and examples of different types of opportunity). In the 1970s, public concern about potential mining around the Great Barrier Reef indicated a need to improve the protection of biodiversity (traction opportunity: increased public awareness and concern). Reducing the threat of decreased water quality to the GBR required a long-term management approach in which a series of potential opportunities were identified and exploited to shift the system to a more desirable state. For example, building the base of scientific evidence on the effects of poor water quality and communicating these findings created public awareness and support for the problem (potential opportunity: education) (Brodie et al. 2012). Through partnership with the Queensland State Government, the GBR Marine Park Authority developed Reef Rescue Plans (2003, 2009), which set out targets, such as reducing pollutants (existing opportunity: policy) and provided economic incentives to landholders to reduce the effects of their land management practices on water quality (existing opportunity: resources) (Brodie et al. 2012). Lastly, through long-term exploitation of potential and existing opportunities, public support and concern regarding effects of poor water quality on the GBR resulted in the GBR Protection Amendment Act 2009 which introduces regulations on water quality of water entering the GBR (Brodie et al. 2012; Day \& Dobbs 2013) (traction opportunity: political support). Traction opportunities have been critical for other aspects of management in the GBR. For example, while the existing zoning of the park is a major hallmark for its management, in 2004 changes to the original zoning to increase no-take areas to $33 \%$ were widely unpopular in some sectors of the community. Some lobby groups rallied hard to ensure that the government implemented the change before the next political cycle. Timing 
and political leadership were critical for implementation (traction opportunity: political cycle).

\section{Conclusion}

Without an opportunity, there is no conservation action (Short et al. 2010). Identifying opportunities for conservation is therefore crucial in achieving conservation goals. We have used existing disciplinary conceptualizations of opportunity to redefine 'conservation opportunity'. In doing so, we have identified three different types of opportunity, each characterized by different leverage points, which can be exploited in the pursuit of conservation objectives. We have also identified four different types of entrepreneur, who are skilled at recognizing and taking advantage of opportunities and who can add value to conservation teams by assisting in translating objectives to action. Our multidisciplinary conceptualization includes a framework for operationalizing conservation opportunity, the main intention of which is to encourage researchers, practitioners and other interested individuals and groups to consider how they can most effectively bring about the change required to support their conservation objectives. To increase the value of this framework we believe research is necessary in four areas: 1) categorizing spatial and temporal characteristics of the sub-systems in which conservation opportunities can manifest to optimize conservation investment across systems; 2) defining the underlying processes that explain and influence human behavior and thus conservation action; 3) identifying the attributes of the different types of conservation opportunities, including any new types, so they can be clearly recognized by entrepreneurs; and 4) exploring the nature of different entrepreneurs to ensure that the most appropriate skill sets can be engaged in conservation teams. This research will advance the capacity of the conservation community to succeed in securing, maximizing the benefit of and increasing the proportion of resources that are available for conservation. 


\section{Acknowledgements}

This research was supported by funding from the ARC Centre of Excellence for Environmental Decisions and the NERP Environmental Decisions Hub. SJH acknowledges funding from the National Science Foundation Coupled Natural-Human Systems Program and DEB-1115025. KM acknowledges financial support from the Institute for Applied Ecology. The authors would like to thank L. Botterill, D. Ireland, D. Pannell, B. Wintle and Y. Ben-Haim for their reviews, as well as helpful comments from two anonymous reviewers. 


\section{References}

Acs, Z. J., and D. B. Audretsch, editors. 2010. Handbook of Entrepreneurship Research. Springer New York Dordrecht Heidelberg, London.

Ajzen, I. 1985. From intentions to actions: A theory of planned behavior in J. Kuhl, editor. Action-control: From cognition to behavior. Springer, Heidelberg.

Ardichvili, A., R. Cardozo, and S. Ray. 2003. A theory of entrepreneurial opportunity identification and development. Journal of Business Venturing 18:105-123.

Armenakis, A. A., S. G. Harris, and K. W. Mossholder. 1993. Creating Readiness for Organizational Change. Human Relations 46:681-703.

Arrow, K. J. 1963. Social choice and individual values. Yale university press.

Balmford, A., and R. M. Cowling. 2006. Fusion or Failure? The Future of Conservation Biology. Conservation Biology 20:692-695.

Ban, N. C., M. Mills, J. Tam, C. C. Hicks, S. Klain, N. Stoeckl, M. C. Bottrill, J. Levine, R. L. Pressey, T. Satterfield, and K. M. A. Chan. 2013. A social-ecological approach to conservation planning: embedding social considerations. Frontiers in Ecology and the Environment 11:194-202.

Baumgartner, F. R., and B. D. Jones 1993. Agendas and instability in American politics. University of Chicago Press, Chigago.

Beedell, J. D. C., and T. Rehman. 1999. Explaining farmers' conservation behaviour: Why do farmers behave the way they do? Journal of Environmental Management 57:165-176.

Begley, T. M., and D. P. Boyd. 1987. Psychological characteristics associated with performence in entrepreneurial firms and smaller businesses. Journal of Business Venturing 2:79-93.

Ben-Haim, Y. 2006. Info-Gap Theory: Decisions Under Severe Uncertainty. Academic Press, London.

Biggs, D., N. Abel, A. T. Knight, A. Leitch, A. Langston, and N. C. Ban. 2011. The implementation crisis in conservation planning: could "mental models" help? Conservation Letters 4:169-183.

Biggs, D., F. Courchamp, R. Martin, and H. P. Possingham. 2013. Legal Trade of Africa's Rhino Horns. Science 339:1038-1039.

Bradach, J. L., T. J. Tierney, and N. Stone. 2008. Delivering on the promise of nonprofits. Harvard Business Review:1-10.

Brockhaus, R. H., and P. Horwitz. 1986. The psychology of the entrepreneur in D. L. Sexton, and R. W. Smilor, editors. The Art and Science of Entrepreneurship. Ballinger, Cambridge, MA.

Brodie, J. E., F. J. Kroon, B. Schaffelke, E. C. Wolanski, S. E. Lewis, M. J. Devlin, I. C. Bohnet, Z. T. Bainbridge, J. Waterhouse, and A. M. Davis. 2012. Terrestrial pollutant runoff to the Great Barrier Reef: An update of issues, priorities and management responses. Marine Pollution Bulletin 65:81-100.

Burgman, M. A., D. B. Lindenmayer, and J. Elith. 2005. Managing landscapes for conservation under uncertainty. Ecology 86:2007-2017.

Chan, K. M. A., R. M. Pringle, J. A. I. Ranganathan, C. L. Boggs, Y. L. Chan, P. R. Ehrlich, P. K. Haff, N. E. Heller, K. Al-Khafaji, and D. P. Macmynowski. 2007. When agendas collide: Human welfare and biological conservation. Conservation Biology 21:59-68.

Chandra, Y., C. Styles, and I. Wilkinson. 2009. The recognition of first time international entrepreneurial opportunities: Evidence from firms in knowledge-based industries. International Marketing Review 26:30-61. 
Clark, T. W. 2002. The Policy Process: A Practical Guide for Natural Resources Professionals. Yale University Press, United States.

CMP. 2013. Open standards for the practice of conservation. Version 3.0, http://cmpopenstandards.org/wp-content/uploads/2014/03/CMP-OS-V3-0-Final.pdf (accessed June 2014).

Cocklin, C., N. Mautner, and J. Dibden. 2007. Public policy, private landholders: Perspectives on policy mechanisms for sustainable land management. Journal of Environmental Management 85:986-998.

Cowling, R. M., and A. Wilhelm-Rechmann. 2007. Social assessment as a key to conservation success. Oryx 41:135-136.

Cumming, G. S., G. Barnes, S. Perz, M. Schmink, K. Sieving, J. Southworth, M. Binford, R. D. Holt, C. Stickler, and T. Van Holt. 2005. An exploratory framework for the empirical measurement of resilience. Ecosystems 8:975-987.

Cundill, G., G. S. Cumming, D. Biggs, and C. Fabricius. 2012. Soft Systems Thinking and Social Learning for Adaptive Management

Pensamiento Sistémico Blando y Aprendizaje Social para Manejo Adaptativo. Conservation Biology 26:13-20.

Day, J. C., and K. Dobbs. 2013. Effective governance of a large and complex crossjurisdictional marine protected area: Australia's Great Barrier Reef. Marine Policy 41:14-24.

Eckhardt, J. T., and S. Shane. 2010. An Update to the Individual-Opportunity Nexus in Z. J. Acs, and D. B. Audretsch, editors. Handbook of Entrepreneurship Research. Springer New York Dordrecht Heidelberg, London.

Ehrlich, P. R., and R. M. Pringle. 2008. Where does biodiversity go from here? A grim business-as-usual forecast and a hopeful portfolio of partial solutions. Proceedings of the National Academy of Sciences of the United States of America 105:11579-11586.

Ekoko, F. 2000. Balancing Politics, Economics and Conservation: The Case of the Cameroon Forestry Law Reform. Development and Change 31:131-154.

Fielding, K. S., D. J. Terry, B. M. Masser, P. Bordia, and M. A. Hogg. 2005. Explaining landholders' decisions about riparian zone management: The role of behavioural, normative, and control beliefs. Journal of Environmental Management 77:12-21.

Fischer, J., G. D. Peterson, T. A. Gardner, L. J. Gordon, I. Fazey, T. Elmqvist, A. Felton, C. Folke, and S. Dovers. 2009. Integrating resilience thinking and optimisation for conservation. Trends in Ecology \& Evolution 24:549-554.

Fishbein, M. 1967. Attitude and the prediction of behaviour. Pages 52-83 in M. Fishbein, editor. Readings in attitude theory and measurement. Wiley, New York.

Fishbein, M., and I. Ajzen, editors. 2005. The influence of attitudes on behavior. Lawrence Erlbaum Associates, New York.

Folke, C., T. Hahn, P. Olsson, and J. Norberg. 2005. Adaptive governance of socialecological systems. Annual Review of Environment and Resources 30:441-473.

Fox, H. E., J. L. Holtzman, K. M. Haisfield, C. G. McNally, G. A. Cid, M. B. Mascia, J. E. Parks, and R. S. Pomeroy. 2014. How Are Our MPAs Doing? Challenges in Assessing Global Patterns in Marine Protected Area Performance. Coastal Management 42:207-226.

Gaglio, C., and J. Katz. 2001. The Psychological Basis of Opportunity Identification: Entrepreneurial Alertness. Small Business Economics 16:95-111.

Game, E. T., G. Lipsett-Moore, R. Hamilton, N. Peterson, J. Kereseka, W. Atu, M. Watts, and H. Possingham. 2011. Informed opportunism for conservation planning in the Solomon Islands. Conservation Letters 4:38-46. 
Gifford, R. 2014. Environmental Psychology Matters. Annual Review of Psychology 65:541579.

Hayes, K. R., S. C. Barry, G. R. Hosack, and G. W. Peters. 2013. Severe uncertainty and info-gap decision theory. Methods in Ecology and Evolution 4:601-611.

Hillson, D. 2002. Extending the risk process to manage opportunities. International Journal of Project Management 20:235-240.

Holcombe, R. 2003. The Origins of Entrepreneurial Opportunities. The Review of Austrian Economics 16:25-43.

Hsieh, C., J. A. Nickerson, and T. R. Zenger. 2007. Opportunity Discovery, Problem Solving and a Theory of the Entrepreneurial Firm. Journal of Management Studies 44:12551277.

Huntley, B., and C. Petersen 2005. Mainstreaming biodiversity in production landscapes. Washington, DC: Global Environment Facility.

Hussain, A., and D. Laband. 2005. The tragedy of the political commons: Evidence from U.S. Senate roll call votes on environmental legislation. Public Choice 124:353-364.

Jacquet, J., J. Hocevar, S. Lai, P. Majluf, N. Pelletier, T. Pitcher, E. Sala, R. Sumaila, and D. Pauly. 2010. Conserving wild fish in a sea of market-based efforts. Oryx 44:45-56.

Kabii, T., and P. Horwitz. 2006. A review of landholder motivations and determinants for participation in conservation covenanting programmes. Environmental Conservation 33:11-20.

Kaiser, F. G. 1998. A General Measure of Ecological Behavior1. Journal of Applied Social Psychology 28:395-422.

Kingdon, J. W. 1984. Agendas, Alternatives, and Public policies. Longman Publishing Group, New York.

Knight, A. T., and R. M. Cowling. 2007. Embracing Opportunism in the Selection of Priority Conservation Areas. Conservation Biology 21:1124-1126.

Knight, A. T., R. M. Cowling, and B. M. Campbell. 2006. An operational model for implementing conservation action. Conservation Biology 20:408-419.

Knight, A. T., R. M. Cowling, M. Difford, and B. M. Campbell. 2010. Mapping human and social dimensions of conservation opportunity for the scheduling of conservation action on private land. Conservation Biology 24:1348-1358.

Knight, F. H. 2012. Risk, uncertainty and profit. Courier Dover Publications, Mineola, New York.

Lewin, C. 2002. RAMP Risk Analysis and Management for Projects. London: Institution of Civil Engineers and the Faculty and Institute of Actuaries in association with Thomas Telford.

Marsh, S. P., D. J. Pannell, and R. K. Lindner. 2000. The impact of agricultural extension on adoption and diffusion of lupins as a new crop in Western Australia. Australian Journal of Experimental Agriculture 40:571-583.

Mills, M., R. L. Pressey, N. C. Ban, S. Foale, S. Aswani, and A. T. Knight. 2013. Understanding characteristics that define the feasibility of conservation actions in a common pool marine resource governance system. Conservation Letters http://dx.doi.org/10.1111/conl.12025.

Mintrom, M., and S. Vergari. 1996. Advocacy Coalitions, Policy Entrepreneurs, and Policy Change. Policy Studies Journal 24:420-434.

Morris, C., and C. Potter. 1995. Recruiting the new conservationists: Farmers' adoption of agri-environmental schemes in the U.K. Journal of Rural Studies 11:51-63.

Naidoo, R., A. Balmford, P. J. Ferraro, S. Polasky, T. H. Ricketts, and M. Rouget. 2006. Integrating economic costs into conservation planning. Trends in Ecology \& Evolution 21:681-687. 
Ney, S., and M. Thompson. 2000. Cultural discourses in the global climate change debate. Pages 65-92 in E. Jochem, J. Sathaye, and D. Bouille, editors. Society, behaviour, and climate change mitigation. Kluwer Academic Publishers, Dodrecht, The Netherlands.

North, D. C. 1995. Five propositions about institutional change. Pages 15-26 in J. Knight, and I. Sened, editors. Explaining social institutions. University of Michigan Press, Ann Arbor.

O'Riordan, T., and A. Jordan. 1999. Institutions, climate change and cultural theory: towards a common analytical framework. Global Environmental Change 9:81-93.

Ostrom, E. 2009. A General Framework for Analyzing Sustainability of Social-Ecological Systems. Science 325:419-422.

Pannell, D. J. 2008. Public benefits, private benefits, and policy mechanism choice for landuse change for environmentla benefits. Land Economics 84:225-240.

Pannell, D. J., G. R. Marshall, N. Barr, A. Curtis, F. Vanclay, and R. Wilkinson. 2006. Understanding and promoting adoption of conservation practices by rural landholders. Australian Journal of Experimental Agriculture 46:1407-1424.

Payne, D. C. 2000. Policy-making in Nested Institutions: Explaining the Conservation Failure of the EU's Common Fisheries Policy. JCMS: Journal of Common Market Studies 38:303-324.

Peterson, G. D., G. S. Cumming, and S. R. Carpenter. 2003. Scenario planning: a tool for conservation in an uncertain world. Conservation Biology 17:358-366.

Plummer, L., J. M. Haynie, and J. Godesiabois. 2007. An Essay on the Origins of Entrepreneurial Opportunity. Small Business Economics 28:363-379.

Polasky, S., S. R. Carpenter, C. Folke, and B. Keeler. 2011. Decision-making under great uncertainty: environmental management in an era of global change. Trends in Ecology \& Evolution 26:398-404.

Pressey, R. L. 1997. Priority conservation areas: towards an operational definition for regional assessments. Pages 337-357 in J. J. Pigram, and R. C. Sundell, editors. National Parks and Protected Areas: Selection, Delimitation, and Management. Centre for Water Policy Research, Armidale, New South Wales.

Pressey, R. L., and M. C. Bottrill. 2009. Approaches to landscape- and seascape-scale conservation planning: convergence, contrasts and challenges. Oryx 43:451-460.

Ray, S., and R. Cardozo. 1996. Sensitivity and creativity in entrepreneurial opportunity recognition: a framework for empirical investigation. Sixth Global Entrepreneurship Research Conference, Imperial College, London.

Regan, H. M., Y. Ben-Haim, B. Langford, W. G. Wilson, P. Lundberg, S. J. Andelman, and M. A. Burgman. 2005. Robust decision-making under severe uncertainty for conservation management. Ecological Applications 15:1471-1477.

Resilience-Alliance. 2010. Assessing resilience in social-ecological systems: Workbook for practitioners. Version 2.0.

Rogers, E. M. 2003. Diffusion of innovations. New York., NY, Free Press.

Rollings, N., and D. Brunckhorst. 1999. Linking ecological and social functions of landscapes: II. Scale and modeling of spatial influence. Natural Areas Journal 19:6572.

Sabatier, P. 1988. An advocacy coalition framework of policy change and the role of policyoriented learning therein. Policy Sciences 21:129-168.

Salafsky, N., R. Margoluis, K. H. Redford, and J. G. Robinson. 2002. Improving the Practice of Conservation: a Conceptual Framework and Research Agenda for Conservation Science 
Mejoramiento de la Práctica de la Conservación: un Marco Conceptual y un Programa Para la Ciencia de la Conservación. Conservation Biology 16:1469-1479.

Sattler, C., and U. J. Nagel. 2010. Factors affecting farmers' acceptance of conservation measures-A case study from north-eastern Germany. Land Use Policy 27:70-77.

Schultz, P. W., and M. Estrada-Hollenbeck. 2008. The use of theory in applied social psychology. Pages 28-49 in L. Steg, A. P. Buunk, and T. Rothengatter, editors. Applied social psychology. Cambridge University Press, Cambridge.

Schwartz, S. H. 1977. Normative influences on altruism. Pages 221-279 in L. Berkowitz, editor. Advances in experimental social psychology.

Seidl, I., O. Schelske, J. Joshi, and M. Jenny. 2003. Entrepreneurship in biodiversity conservation and regional development. Entrepreneurship \& Regional Development 15:333-350.

Shane, S., and S. Venkataraman. 2000. The Promise of Entrepreneurship as a Field of Research. The Academy of Management Review 25:217-226.

Shane, S. A. 2003. A general theory of entrepeneurship: the individual-opportunity nexus. Edward Elgar Publishing Inc., Northampton, MA.

Short, J. C., D. J. Ketchen, C. L. Shook, and R. D. Ireland. 2010. The Concept of "Opportunity" in Entrepreneurship Research: Past Accomplishments and Future Challenges. Journal of Management 36:40-65.

Simon, H. A. 1991. Bounded Rationality and Organizational Learning. Organization Science 2:125-134.

Sine, W. D., and R. J. David. 2003. Environmental jolts, institutional change, and the creation of entrepreneurial opportunity in the US electric power industry. Research Policy 32:185-207.

Stern, P. C., T. Dietz, T. Abel, G. A. Guagnano, and L. Kalof. 1999. A value-belief-norm theory of support for social movements: The case of environmentalism. Human Ecology Review 6:81-98.

Thompson, J. L. 2002. The world of the social entrepreneur. International Journal of Public Sector Management 15:412-431.

Traoré, N., R. Landry, and N. Amara. 1998. On-Farm Adoption of Conservation Practices: The Role of Farm and Farmer Characteristics, Perceptions, and Health Hazards. Land Economics 74:114-127.

Walker, B., S. Carpenter, J. Anderies, N. Abel, G. S. Cumming, M. Janssen, L. Lebel, J. Norberg, G. D. Peterson, and R. Pritchard. 2002. Resilience management in socialecological systems: a working hypothesis for a participatory approach. Ecology and Society 6:14. [online] URL: http://www.consecol.org/vol16/iss11/art14/

Walker, B., L. Gunderson, A. Kinzig, C. Folke, S. Carpenter, and L. Schultz. 2006. A handful of heuristics and some propositions for understanding resilience in social-ecological systems. Ecology and Society 11:13.

Ward, S., and C. Chapman. 2003. Transforming project risk management into project uncertainty management. International Journal of Project Management 21:97-105.

Wejnert, B. 2010. A conceptual threshold model of adoption of innovations as a function of innovation's value and actor's chacteristics. Journal of Asia-Pacific Business 11:197217. 
Table 1: The literatures reviewed and the opportunities which they identify

\begin{tabular}{lccc}
\hline Literature & \multicolumn{3}{c}{ Conservation opportunity type } \\
\hline & Traction & Potential & Existing \\
\hline Behavior and adoption & $\checkmark$ & $\checkmark$ & $\checkmark$ \\
Business, entrepreneurs and institutions & $\checkmark$ & $\checkmark$ & $\checkmark$ \\
Public policy & $\checkmark$ & & \\
Resilience & $\checkmark$ & $\checkmark$ & \\
Uncertainty and risk & $\checkmark$ & $\checkmark$ & $\checkmark$ \\
Information-gap decision theory & $\checkmark$ & & $\checkmark$ \\
Mainstreaming & $\checkmark$ & $\checkmark$ & \\
\hline
\end{tabular}

Table 2: Leverage points for three different types of conservation opportunity, traction, potential and existing within biophysical, social, political and economic sub-systems.

Conservation opportunity type

\begin{tabular}{|c|c|c|c|}
\hline & Traction & Potential & Existing \\
\hline Biophysical & $\begin{array}{l}\text { - Scientific evidence } \\
\text { - Disease outbreaks } \\
\text { - Natural disasters }\end{array}$ & - Scientific methods & - Scientific evidence \\
\hline Social & - Public concern & $\begin{array}{l}\text { - Attitudes/perceptions } \\
\text { - Willingness } \\
\text { - Credibility } \\
\text { - Education }\end{array}$ & $\begin{array}{l}\text { - Capacity } \\
\text { - Leadership }\end{array}$ \\
\hline Political & $\begin{array}{l}\text { - Political support } \\
\text { - Political cycles }\end{array}$ & $\begin{array}{l}\text { - Access to policy- } \\
\text { makers }\end{array}$ & $\begin{array}{l}\text { - Legislation } \\
\text { - International } \\
\text { agreements }\end{array}$ \\
\hline Economic & - Funding cycle & - Funding proposal & $\begin{array}{l}\text { - Technology } \\
\text { - Resources }\end{array}$ \\
\hline
\end{tabular}


Table 3: Types of actors involved in recognizing and exploiting conservation opportunities and their dominant characteristics and roles.

\begin{tabular}{|c|c|c|}
\hline Actor & Characteristics & Role \\
\hline $\begin{array}{l}\text { Business } \\
\text { entrepreneur } \\
\text { (Eckhardt \& } \\
\text { Shane 2010) }\end{array}$ & $\begin{array}{l}\text { Change agent: of market by creating } \\
\text { new businesses or products } \\
\text { Entrepreneurial skills: strong } \\
\text { management skills and team building } \\
\text { ability; awareness of the economic } \\
\text { sub-system; connected to a network } \\
\text { of business and market peers } \\
\text { Personal attributes: tolerance for } \\
\text { ambiguity; high need for } \\
\text { achievement; high self-efficacy }\end{array}$ & $\begin{array}{l}\text { - Focus on creating and } \\
\text { exploiting new business } \\
\text { opportunities } \\
\text { - Aim to earn return on } \\
\text { investment }\end{array}$ \\
\hline $\begin{array}{l}\text { Policy } \\
\text { entrepreneur/ } \\
\text { advocate } \\
\text { (Mintrom \& } \\
\text { Vergari 1996) }\end{array}$ & $\begin{array}{l}\text { Change agent: of policy by creating } \\
\text { policy change } \\
\text { Entrepreneurial skills: strong } \\
\text { negotiating skills; awareness of the } \\
\text { policy sub-system; visible in policy- } \\
\text { making circles, action-oriented, } \\
\text { organizational and personal resource } \\
\text { abundance } \\
\text { Personal attributes: persistent; } \\
\text { persuasive; influential }\end{array}$ & $\begin{array}{l}\text { - Bring new policy ideas into } \\
\text { "good currency" } \\
\text { - Sell ideas to create dynamic } \\
\text { policy change } \\
\text { - Define policy problems in } \\
\text { attractive ways with } \\
\text { appropriate policy responses } \\
\text { for a defined audience } \\
\text { - Shape the terms of the policy } \\
\text { debate } \\
\text { - Build and support coalitions } \\
\text { to support policy ideas }\end{array}$ \\
\hline $\begin{array}{l}\text { Social } \\
\text { entrepreneur } \\
\text { (Thompson } \\
\text { 2002) }\end{array}$ & $\begin{array}{l}\text { Change agent: of people's lives by } \\
\text { providing social support } \\
\text { Entrepreneurial skills: action- } \\
\text { oriented or passive; leader or } \\
\text { follower; donator; volunteer or } \\
\text { business-oriented } \\
\text { Personal attributes: altruistic; caring; } \\
\text { helpful; concerned }\end{array}$ & $\begin{array}{l}\text { - Create social capital } \\
\text { - Seek to improve people's } \\
\text { lives } \\
\text { - Recruit and motivate others } \\
\text { - Secure resources } \\
\text { - Listen to and respond to } \\
\text { community needs }\end{array}$ \\
\hline $\begin{array}{l}\text { Conservation } \\
\text { entrepreneur } \\
\text { (e.g., } \\
\text { government, } \\
\text { NGO, } \\
\text { individuals) } \\
\text { (Seidl et al. } \\
\text { 2003) }\end{array}$ & $\begin{array}{l}\text { Chang agent: of ecosystems by } \\
\text { generating support for conservation } \\
\text { action } \\
\text { Entrepreneurial skills: high capacity } \\
\text { to manage and co-ordinate; } \\
\text { contextual knowledge of } \\
\text { local/regional needs; adaptable; } \\
\text { encouraging and supportive; }\end{array}$ & $\begin{array}{l}\text { - Adopt business principles in } \\
\text { the context of conservation } \\
\text { - Develop niche markets/ } \\
\text { businesses for biodiversity } \\
\text { conservation and ecosystem } \\
\text { service provision } \\
\text { - Integrate people and groups } \\
\text { and sub-systems } \\
\text { - Generate new combinations } \\
\text { of resources }\end{array}$ \\
\hline
\end{tabular}


understanding of social-ecological

- Create and promote products system and processes

Personal attributes: creative;

dedicated; tenacious 


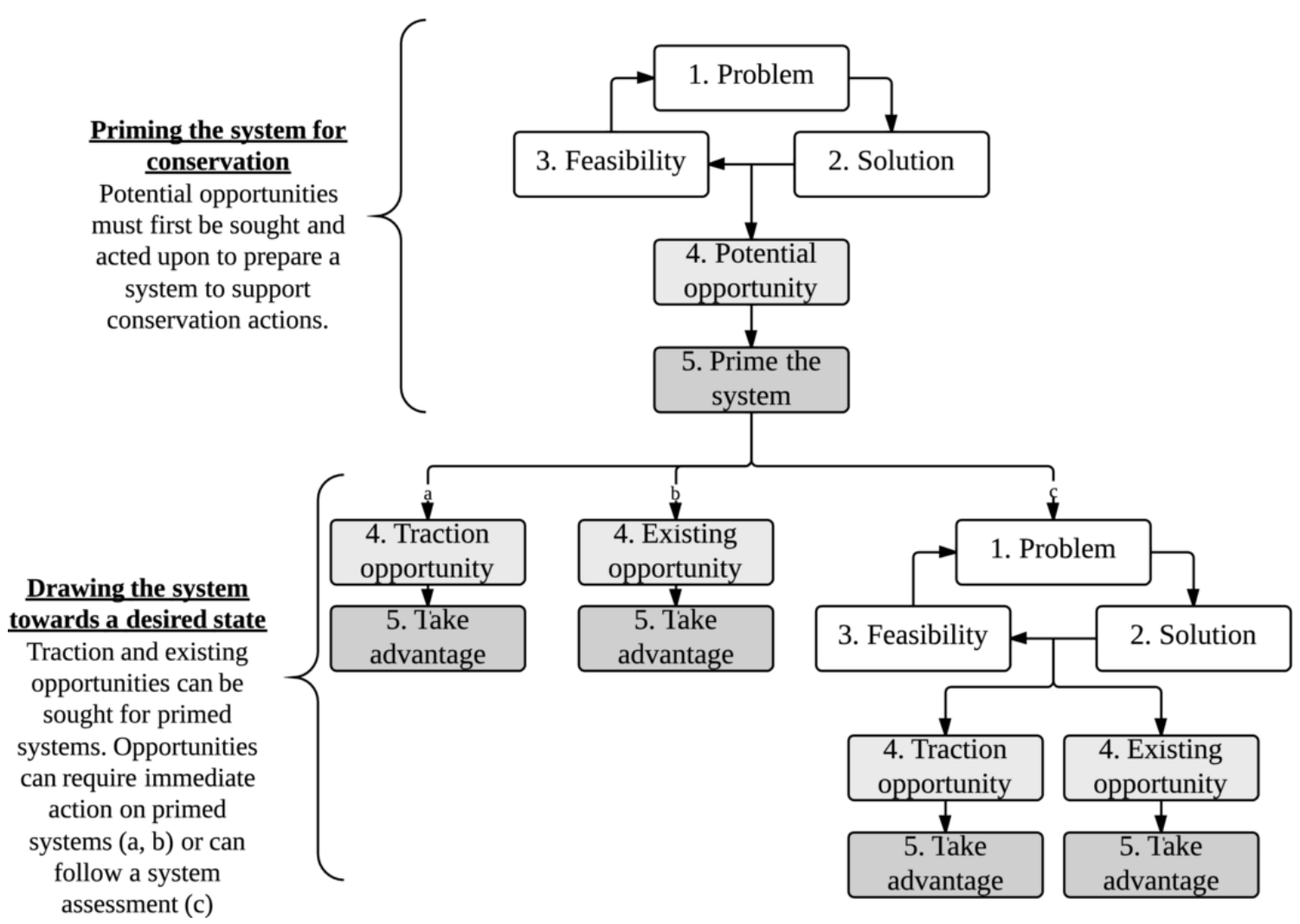

Figure 1: A conservation opportunity relates to a specific problem-solution pair which manifests differently in different social-ecological systems. Successful conservation identification/creation and exploitation typically occurs across five stages: 1) characterize the system and define any problems; 2) identify potential solutions; 3) assess the feasibility; 4) identify or create the opportunity (traction, potential, existing); and 5) take advantage of the opportunity. Note: the recognition and development of an opportunity is an iterative and often non-linear process that can involve taking advantage of multiple opportunities associated with a problemsolution pair to achieve the primed system or desired system state. Often the system will need to be primed to respond to a very specific problem (e.g., changing attitudes towards a species). The readiness of the system is relative to a problem, and so a primed or desired system state can end up back at a primed state for a new problem or can end up in an unprimed state relative to a new problem; the desired system state is not necessarily an end point. The position of an actor in this process is relative to some problem. 


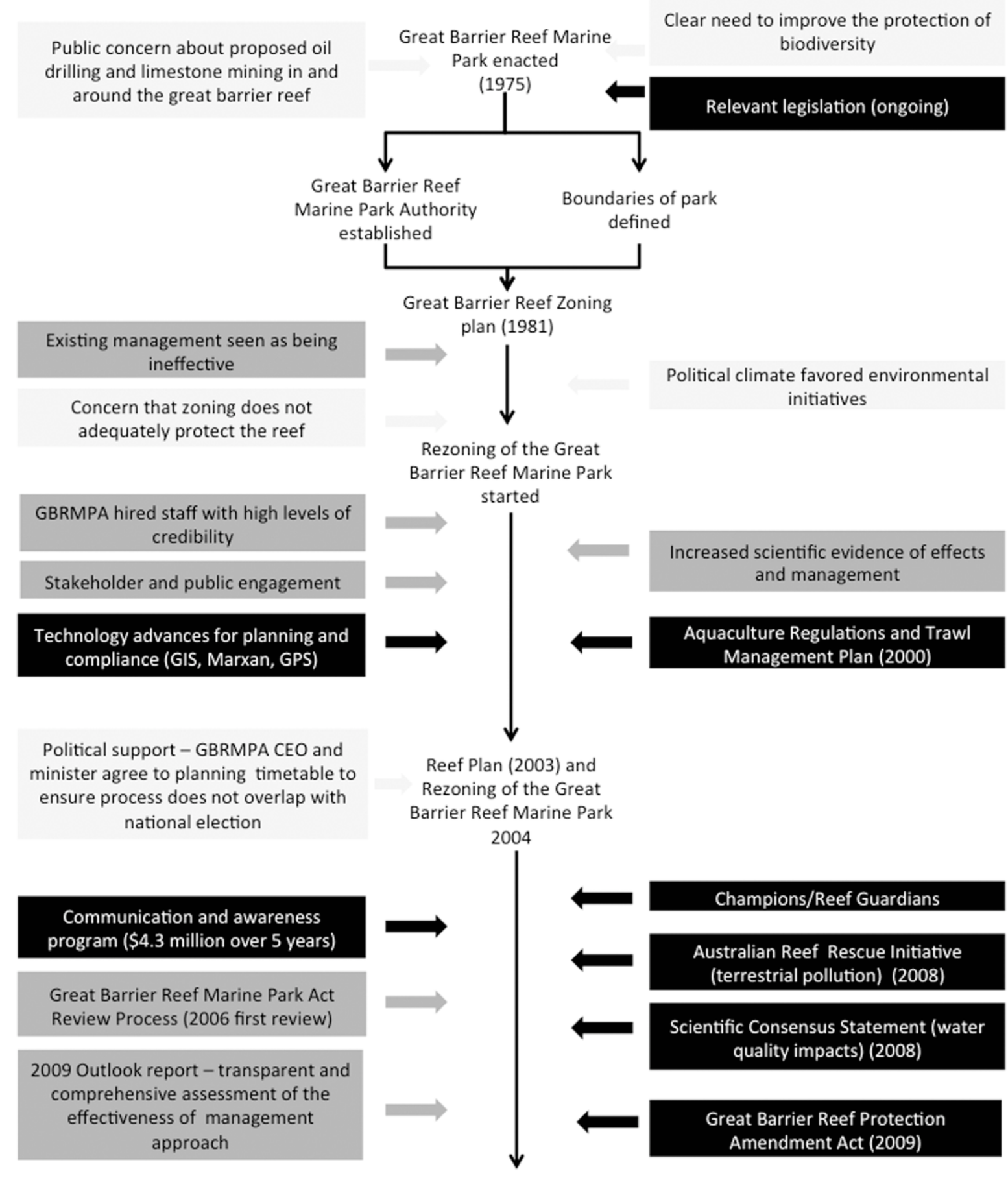

Figure 2: A time line of conservation opportunity and action on the Great Barrier Reef

(GBR) from 1970s to current day. Key opportunities: traction (green), potential (blue) and existing (orange) are summarized for the evolution of establishing the Great Barrier Reef Marine Park, park management and zoning:. On the right side of the figure is a timeline of 
relevant legislation and management plans that support the conservation of the GBR, and that relate to the opportunities presented. .

*Relevant Legislation that supported declaration and ongoing updates to the management of the GBR is:

1963 - Convention of the International Trade of Endangered Species of Wild Flora and Fauna (CITES)

1972 - World Heritage Convention

1979 - Convention of the Conservation of Migratory Species of Wild Animals (CMS)

1982 - UN Convention of the Law of the Sea

1986 - Convention for the Protection of the Natural Resources and Environment of the South Pacific Region (SPREP Convention)

1992 - Agenda 21 (Ch. 17) and Rio Declaration of Environment and Development

1995 - Global Program of Action for the Protection of the Marine Environment from Land based activities (GPA) 